\title{
ADAPTATION INTO ISLAMIC EDUCATION 4.0: AN APPROACH TO REDESIGNING A SUSTAINABLE ISLAMIC EDUCATION IN THE POST PANDEMIC ERA
}

\author{
Mahrus As'ad \\ Institut Agama Islam Negeri Metro \\ Iringmulyo, Metro, Lampung, Indonesia, 34112 \\ E-mail: mahrusasadsyarif@gmail.com

\begin{tabular}{c|c|c}
\hline Received: & Revised: & Approved: \\
24/02/2021 & $28 / 04 / 2021$ & $20 / 05 / 2021$ \\
\hline
\end{tabular} \\ DOI : https:// doi.org/10.32332/akademika.v26i1.3122

\begin{abstract}
(ब) (1) (-)
Adaptation Into Islamic Education 4.0: An Approach to Redesigning A Sustainable Islamic Education In The Post Pandemic Era Licensed Under a Creative Commons Attribution-ShareAlike 4.0 International License
\end{abstract}

\begin{abstract}
The unpresendented presence of Pandemic Covid 19 in the beginning of 2020 has almost paralyzed the world of global education, including Indonesia's Islamic education as one of the biggest Islamic education systems in the world. Anticipating the possibility of similar incidents in the future, the Indonesia's Islamic education needs to redesign its learning approach in order to create a new learning model that is more resilient, and meet the needs and the demands of Industri 4.0: Education 4.0. Unlike the conventional approache having been used so far, this new desired approach departs from a paradigm that places the students at the center of learning with the involvement of the use of on-line classes to explore them to the fullest. Philosophically, there is a resemblance of Education 4.0 orientation to the Islamic education's concept of 'cradle-to-grave learning', which emphasizes the creation of life-long learners and teachers to enable them to play positive and constructive roles in today work environment and in the innovative society in general. Using the descriptive-analytical method, this paper seeks to examine the the urgency and the readiness of the Indonesia's Islamic Education to tansform into education 4.0 and its crusial challenges in facing this demand.
\end{abstract}

Keywords: Tansformation Into Education 4.0, Personalized Learning, Lifelong

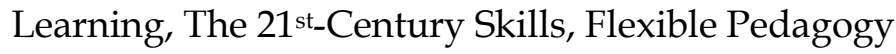

\section{A. Introduction}

The world of education around the world today is going through a period of dramatic change. The education institutions has been forced to close their doors 
nationwide ${ }^{1}$. A current study shows that there are more than 1.6 billion children and youth in 161 countries to be out of school due to this pandemic ${ }^{2}$. This amount is close to $80 \%$ of the world's enrolled student, which about a quarter could be muslim students, and around 60 million of them from Indonesia ${ }^{3}$. This education crisis will certainly have a far-reaching impact for their future due to lost their instructional time and shortfalls in education in general ${ }^{4}$.

With the start of the new normal, the education authorities across the world, including of the muslim countries like Indonesia, attempt to change their education strategy by incorporating an innovative way which is often called in the term of "study from home" to teach the students to maintain the continuity of their education from home or through online education or remote learning. By online education or remote learning means electronically supported education that relies on the use of internet for teacher and student interaction and the distribution of class materials in order to avoid the physical classes. It includes the use of digital devices, such as smartphone and personal computer (PC), which can enrich the learning environment with much more flexibility than a traditional classroom ${ }^{5}$. This change will color the portrait of the muslim generation in the future which must be different from their predecessors in the era of ten or twenty years ago.

Due to its ad-hoc nature, many education observers question the effectiveness of this new model of education to answer the educational needs the students should receive $^{6}$. For this reason, many education observers then encourage the need for radical learning reforms in order to build a stronger and more permanent education system in the post-pandemic era ${ }^{7}$. In essence, as stated by Bindra ${ }^{8}$, that mode of education, including Islamic Education, in the post-pandemic era cannot be the same again. The aim is, in addition to building an education system that will withstand future crises, but also to meet the new educational needs to respond to the demands of Industry 4.09,

1 Zubair Torwali, "Education and a Pandemic," April 30, 2020, accessed September 27, 2020, www.thenews.com/pk.

2 Jaime Saavedra, "Educational Challenges and Opportunities of the Coronavirus (COVID-19) Pandemic," March 30, 2020, accessed September 19, 2020, blogs.worldbank.org/education/.

3 Gogot Suharwoto, "Pembelajaran Online Di Tengah Pandemi Covid-19, Tantangan Yang Mendewasakan," April 2, 2020, accessed June 23, 2020, www.timesindonesia.com.

4 Ollia Horton, "Covid-19 Is Hampering Access to Education Particularly in Africa," September 19, 2020, accessed September 2020, https://www.rfi.fr/en/international/20200909.

${ }^{5}$ Lily Nyariki, "Africa Supports Reading and Learning during the COVID-19 Pandemic," April 23, 2020, accessed September 27, 2020, https://www.globalpartnership.org/.

6 S Parviz, "Schools Set to Open Sept. 5 amid Pandemic," September 5, 2020, accessed October 14, 2020, https://www.tehrantimes.com/news; Gonzalo Fuentes, "The COVID-19 Pandemic Has Changed Education Forever," April 29, 2020, accessed September 19, 2020, https://www.weforum.org/.

7 Gogot Suharwoto, "Pembelajaran Online Di Tengah Pandemi Covid-19, Tantangan Yang Mendewasakan."

8 Jaspreet Bindra, "Education in the Post-Pandemic World Cannot Be the Same Again," June 25, 2020, accessed September 19, 2020, https:/ / www.livemint.com/.

9 Jean Marc Bernard, Brahima Coulibaly, and Rebecca Winthroup, "Education Is Crucial to Africa's COVID-19 Response," June 4, 2020, accessed September 27, 2020, https://www.brookings.edu/. 
in which human and technology aligne together to enable new possibilities ${ }^{10}$. This means that Education 4.0, as the respond of the demand of Industry 4.0, can be an appropiate option as the basis for developing the futuristic Indonesia Islamic education model for addressing these demands. The question is how the readiness of the Indonesia Islamic education to make this project in reality. What are the crucial challenges it should address?

Using a descriptive-analytical method 11 , this paper seeks to examine to what extent of the readiness of Indonesian Islamic Education to welcome leapfrogging Islamic Education 4.0. For this purpose, it should be explained what Islamic Education 4.0 means, its fundamenat features, its urgency for the future of Islamic education nationally. Then, the discussion will be focused on the crucial challenges faced by the Islamic Education to welcome this transformation. Due to the limitedness of the materials, data are obtained from various sources both in English and Indonesian, including 'gray' literatures, through the Google searching machine.

\section{B. Education 4.0: The Meaning}

In their article entitling "Quo Vadis, Education 4.0?", Sirůček and Džbánková12 said that the term Education 4.0 is as another of the "cool" concepts which do not have a more precise and generally accepted definition. Furthermore, Maria, et al ${ }^{13}$ said, many people often talk about it, but they do not know what that is all about. This could be due to the topic of education 4.0 is considered new. This is not intended to clarify this statement. But it is just to show that the term Education 4.0 denotes a lot of meaning, such as the concept of education in the digital era ${ }^{14}$, a futuristic vision on education ${ }^{15}$, a new learning system ${ }^{16}$, model of education for the future ${ }^{17}$, a futuristic ecosystem of education ${ }^{18}$, the current education system along with the technology and the teaching method ${ }^{19}$ and a new learning society ${ }^{20}$. Each of these terms may have a

10 Anealka Aziz Hussin, “Education 4.0 Made Simple: Ideas for Teaching," International Journal of Education E Literacy Studies 6, no. 3 (2017): 92-98.

11 Jujun S. Suria Sumantri, Penelitian Ilmiah, Kefilsafatan, dan Keagamaan: Mencari Paradigma Kebersamaan" in Mastuhu and Deden Ridwan, Tradisi baru penelitian agama Islam: tinjauan antardisiplin ilmu (Bandung: Nuansa, 2001).

12 Pavel Sirůček and Zuzana Džbánková, “Quo Vadis, Education 4.0?," The 12th International Days of Statistics and Economics, Prague. (September 6, 2018).

13 Meylinda Maria, Faaizah Shahbodin, and Naim Che Pee, "Malaysian Higher Education System towards Industry 4.0 - Current Trends Overview," AIP Conference Proceedings 2016 (n.d.).

14 Anas Abdelrazeq et al., "Teacher 4.0: Requirements of The Teacher of The Future in Context of The Fourth Industrial Revolution," ICERI, Seville Nov, 16th - Nov, 14th (2016).

${ }^{15}$ Chea, C. C. and Huan, J. T. J., "Higher Education 4.0: The Possibilities and Challenges," Journal of Social Sciences and Humanities 5, no. 2 (2019): 81-85.

16 Vichian Puncreobutr, "Education 4.0: New Challenge of Learning," St. Theresa Journal of Humanities and Social Sciences 2, no. 2 (July 2016).

17 Shahroom, A. A. and Hussin, N, "Industrial Revolution 4.0 and Education," International Journal of Academic Research in Business and Social Sciences 8, no. 9 (2018).

18 Srivastava, A. K, "Is Education 4.0 the Future of Learning?," n.d., accessed November 7, 2019, https:/ / www.indiatoday.in/.

${ }^{19}$ Meylinda Maria, Faaizah Shahbodin, and Naim Che Pee, "Malaysian Higher Education System towards Industry 4.0 - Current Trends Overview." 
specific meaning depending on which point of view of an expert or a certain group of experts prefer referring to and their giving a specific respond to the needs of Industry 4.0. Whichever term is used for Education 4.0, they are in agreement that this term talks about the importance of how to reform today's education system to face the demands of innovative society in the digital era, and in responding to platforms of Industry $4.0^{21}$. In more detail22, regarded that, Education 4.0 is to

responds to the needs of "industry 4.0 " or the fourth industrial revolution, where man and machine align to enable new possibilities; harnesses the potential of digital technologies, personalised data, open sourced content, and the new humanity of this globally-connected, technology-fueled world; and establishes a blueprint for the future of learning - lifelong learning - from childhood schooling, to continuous learning in the workplace, to learning to play a better role in society.

For Education 4.0, the traditional ways of implementing education are not enough; it should be redefined to match the needs of the changing world ${ }^{23}$. In this context, Dunwill ${ }^{24}$, as quoted by Lawrence, et $\mathrm{al}^{25}$, defined Education 4.0 as the use of technology in the teaching and learning contexts to enable the human-machine interface to look more universal that contributes to quick revolution in innovation. Hence, learners of Education 4.0 will not learn to use textbooks, pens, and essay in traditional classrooms. Instead, the remote learners are allowed to access the internet and enroll in courses through a variety of open online courses, video chats, or voice calls to learn more dynamic material about the same students. In the language of Sharma ${ }^{26}$, that they may [not?] learn as much as they do.

\section{Emphasis}

Education 4.0 aims at creating graduates as creative members of society and employees who can play a valuable role in the new workspace as well27. For this reason, what should be redefined about the education today is not only its vision,

20 Sunan Sripai, Jesada Boonmahome, and Jitirat SaengLoetuthai, "Indicators of the Characteristics of the Graduates of Rajabhat Universities at the Leap Frogging to the Education 4.0," International Journal of Science and Research (IJSR) 7, no. 10 (October 2018).

21 Anas Abdelrazeq et al., "Teacher 4.0: Requirements of The Teacher of The Future in Context of The Fourth Industrial Revolution"; Pavel Sirǔček and Zuzana Džbánková, "Quo Vadis, Education 4.0?"; Irma Kunnari, Ho Thi Hanh Tien, and Thanh-Lam Nguyen, "Rethinking Learning Towards Education 4.0," HAMK Unlimited Journal, n.d., accessed January 21, 2020, https://unlimited.hamk.fi/.

22 Peter Fisk, “Education 4.0," 2017, accessed January 24, 2020, https://www.thegeniusworks.com/.

${ }^{23}$ Glaucio Messias et al., "Education 4.0 and 21st Century Skills: A Case Study with Robotics Activities in Classroom," Anais do XXIX Simpósio Brasileiro de Informática na Educação (SBIE) (2018).

24 Ethan Dunwill, "4 Changes That Will Shape the Classroom of the Future: Making Education Fully Technological," n.d., accessed October 16, 2019, https://elearningindustry.com/.

25 Rasika Lawrence, Lim Fung Ching, and Haslinda Abdullah, "Strengths and Weaknesses of Education 4.0 in the Higher Education Institution," International Journal of Innovative Technology and Exploring Engineering (IJITEE) 9, no. (December 23, 2019): 511-518.

26 Manisha Sharma, "Teacher in a Digital Era," Global Journal of Computer Science and Technology (G) 17, no. 3 (2017): 11-14.

27 Matthew Lynch and Ido Yerushalmi, "Six Ways to Get Your School on the Education 4.0 Train," June 7, 2018, accessed January 23, 2020, http:/ / blogs.edweek.org/. 
curriculum, system of learning management, learning methods or approach, but also all roles the stakeholders play in order to create a new learning ecosystem, which is compatible with the demands of an inevitable change over the years ahead. In short, all matters related to teaching-learning activities, and education in general, should be reformed, and be freed from the old mindsets ${ }^{28}$. For this purpose, they need a more practical and realistic based approach to the teaching and learning for preparing the graduates for their future life and work ${ }^{29}$.

This futuristic education approach offers a new paradigm of how to build a fair and self-sustaining model for education which can give the graduates the tools to become active lifelong learners in a diverse and pluralistic changing society. The emphasis is on how to place the learners at the center of the learning ecosystem and empowering them to structure their individual problem keeping in mind to the final outcome. With such an emphasis, the learners are prepared to become independent learners which can determine their own way of learning freely, without any intervention from anyone outside themselves ${ }^{30}$. They are allowed to develop their ability to apply technology to discover new innovation and possibilities that are beneficial for the betterment of human life in the society of innovative era ${ }^{31}$.

This implays the need of building education stakeholders such as learners, teachers, and industry partners, and the society of graduate users in general, to redefine their roles for the creation of a new ecosystem that mutually supports the creation of graduates who can easily orientate themselves in constantly changing word and job opportunities, or even have the ability to create these actively ${ }^{32}$ Hence, teachers can no longer restrict their work to a school environment but need collaboration with "outside partners" to give the learners learning possibilities and innovation platforms. Otherwise, the learners can be encouraged to build their own professional connections. Industry partners and the graduate user society in general, need to recognize the added value of collaboration with education ${ }^{33}$.

\section{Features}

With placing the learners as the centre of learning, the reform intended is not only on the teaching-learning approach or method but also on the content of curriculum. Hence, this reform no longer departs from the subject to be taught, but rather on the kind of competencies must be given to the learners in order to make them creative and entrepreneurial, and capable to think critically and solve the problems of their future confidently.

${ }^{28}$ Chea, C. C. and Huan, J. T. J., "Higher Education 4.0: The Possibilities and Challenges.”

29 Rasika Lawrence, Lim Fung Ching, and Haslinda Abdullah, "Strengths and Weaknesses of Education 4.0 in the Higher Education Institution"; Manisha Sharma, "Teacher in a Digital Era."

30 Jocelyn Andaya, "Education 4.0: Challenges and Directions," November 28, 2018, accessed October 10, 2019, http:// patef-update.org/.

${ }^{31}$ Delipiter Lase, "Pendidikan Di Era Revolusi Industri 4.0," JCTES 1, no. 1 (2019): 28-43; Sigit Priatmoko, "Memperkuat Eksistensi Pendidikan Islam Di Era 4.0," Ta'lim, Jurnal Studi Pendidikan Islam 1, no. 2 (2018); Vichian Puncreobutr, "Education 4.0: New Challenge of Learning."

32 Manisha Sharma, "Teacher in a Digital Era"; Pavel Sirůček and Zuzana Džbánková, "Quo Vadis, Education 4.0?"

${ }^{33}$ Irma Kunnari, Ho Thi Hanh Tien, and Thanh-Lam Nguyen, "Rethinking Learning Towards Education 4.0." 
By competency means more than just the acquisition of knowledge and skills. It involves the mobilisation of knowledge, skills, attitudes and values to meet the complex demands of innovative society ${ }^{34}$. For this purpose, the learners need to be provided with a set of specific competencies which World Economic Forum 2015 formulated in the concept of "the 21st Century Skills".

These skills include 16 skills which are broadly devided into three categories: (1) foundational literacies, (2) competencies, and (3) character qualities. Fundational literacies represent how learners apply core skills to everyday tasks upon which they need to build more advanced and equally important competencies and character qualities. This includes the globally assessed skills of literacy and numeracy, scientific literacy, ICT literacy, financial literacy, and cultural and civic literacy. In the past, being able to understand written texts and quantitative relationships was sufficient for entry into the workforce. But now, these skills represent just the starting point on the path towards mastering the $21^{\text {st_-Century Skills. }}$

Competencies describe how students approach complex challenges. For example, critical thinking is the ability to identify, analyse and evaluate situations, ideas and information in order to formulate responses to problems. Creativity is the ability to imagine and devise innovative new ways of addressing problems, answering questions or expressing meaning through the application, synthesis or repurposing of knowledge. Then, communication and collaboration involve working in coordination with others to convey information or tackle problems. Such competencies are essential to the $21^{\text {st }}$ Century workforce, where being able to critically evaluate and convey knowledge, as well as work well with a team, has become the norm.

Furthermore, character qualities describe how learners approach their changing environment. Amid rapidly changing world, character qualities such as persistence and adaptability ensure greater resilience and success in the face of obstacles. Curiosity and initiative serve as starting points for discovering new concepts and ideas. Leadership and social and cultural awareness involve constructive interactions with others in socially, ethically and culturally appropriate ways. More spesifically, Chea and Huan ${ }^{35}$ characterize Education 4.0 in five salient features which can provide a lot of benefits for anyone involving in the teaching and learning activities. Firstly, diverse time and place. Here, the learners are allowed to learn at different times in different places. The use of E-learning tools facilitates opportunities for remote, self-paced learning learners. Flipped classrooms will be implemented in which the theoretical part is learned outside the classroom, while the practical one is in face-to-face classroom.

Secondly, personalised learning in which the learners can learn with learning devices that go along with their capabilities. High achiever learners on a particular subject will be challenged with harder tasks; learners in difficulties will practice more. All learners will be reinforced during their individual learning processes to get positive learning experiences and to diminish them losing confidence about their academic abilities. In this way, teachers can see the areas the learners need extra help. Thirdly, flexible discovery. Although every subject eventually leads to the same learning outcomes, the way to them can vary for each. Similar to the personalised learning experience, the learners will be able to modify their learning process with devices they need. They can learn with different devices, programs, and techniques based on their own preference.

${ }^{34}$ FICCI-EY, ed., "Leapfrogging to Education 4.0: Learner at the Core, India.” (Federation of Indian Chambers of Commerce and Industry, 2017).

${ }^{35}$ Chea, C. C. and Huan, J. T. J., "Higher Education 4.0: The Possibilities and Challenges.” 
Fourthly, modular and project based. Due to careers are adapting to the future freelance economy, learners today will engage in project-based learning and working. Hence, they should be acquainted with project-based learning before their real work begins in the future life. Here the organizational, collaborative, and time management skills can be taught as basics each learner can use in their further academic careers. Fifthly, practical application. Thus, experience in a particular field will be emphasised within courses. More opportunities are provided for learners to obtain real-world skills that are representative to their jobs. It means that curriculum will create more room for learners to fulfill internships, mentoring and collaboration projects.

\section{E. Role of Teachers}

With Education 4.0, some teachers assume that its personalized learning philosophy will give them more work, but essentially it is not. Conversely, it is beneficial for teachers since they can better meet the specific needs of the learners. As Sharma ${ }^{36}$ remarked, through Education 4.0 teachers ultimately teach the learners, not the classes. However, it does not mean there is not collective education. It just means that teaching-learning aktivities are given importance to personalized needs and desires, that the individual should mean something within the classes ${ }^{37}$. Based on this paradigm, the role of teachers has changed dramatically, becoming facilitators to facilitate the learners to develop their existing skills that enables them to be more active in class and to keep in creativity ${ }^{38}$. With their new role, teachers 4.0 must be ready with their duties to lead learning in any situation. They must have sufficient competence in their knowledge base and confidence, and be empathic to students needs and individual learning style.

Borrowing the Biggs language, as quoted by Bye ${ }^{39}$, he/she must be able to create a learning environment that facilitates learning activities that in turn make each of his/her learners achieve their desired learning outcomes in maximum way in the process of becoming a life-long learner ${ }^{40}$. This means that teachers must be good at managing learning activities to guarantee their effectiveness in any situation and condition. Teachers must also be good at using their skills in such a way so that students can follow the development of knowledge and information that is very easy to change. Thus, the same as the students, teachers 4.0 must also be willing to play

${ }^{36}$ Manisha Sharma, "Teacher in a Digital Era."

37 Lisa Chesser, "Modern Trends in Education: 50 Different Approaches to Learning," March 5, 2019, accessed May 7, 2020, www.teachthought.com.

38 Peter Fisk, "Education 4.0"; Matthew Lynch and Ido Yerushalmi, "Six Ways to Get Your School on the Education 4.0 Train"; Irma Kunnari, Ho Thi Hanh Tien, and Thanh-Lam Nguyen, "Rethinking Learning Towards Education 4.0."

39 Robin T. Bye, "The Teacher as a Facilitator for Learning Flipped Classroom in a Master's Course on Artificial Intelligence," Agustus 2017, www.researchgate.net/.

${ }^{40}$ Katherine Hoekman, "The Teacher as Facilitator for Independent Learning," Gifted (1996), accessed December 12, 2020, https:/ / www.academia.edu/2627694/The_teacher_as_facilitator_for_independent_learning; Peter Fisk, "Education 4.0." 
their role as lifelong teachers that never cease to learn ${ }^{41}$. It includes in terms of how to control and use digital learning devices for everyday school teaching and learning ${ }^{42}$.

However, the transformation of Education 4.0 does not mean that it can further the teachers from their tradisional role as an educator. Rather, in multi-diversified cultural countries, such as Indonesia, in whch the indigenous values and religisity are believed as the key elements for the identity of the learners and people in general, the role of teachers as an educator must not be left behind, if necessary, it must be strengthened ${ }^{43}$. If they are not careful about this, uncontrolled digital learning devices penetration in education 4.0 can threaten learning. For example, robots can be entrusted to carry out the task of teaching. However, using the language of Sirůček and Džbánková44, they cannot replace the cantor. This means that the role of teacher as an educator is irreplaceable in education 4.0.

\section{F. Urgency}

Besides the global demand, transformation into Education 4.0 is a crucial for the Indonesia Islamic education and the national education in general, in the PostPandemic era. According to the 2018 World Economic Forum (WEF), Indonesia is claimed to have a strong potential to realize the transformation of Education $4.0^{45}$. So, the Indonesia's strength to bring its Islamic education into education 4.0 is also widely open. Its relatively good connectivity and massive infrastructure development ${ }^{46}$ enable Indonesia to become the top 10 world economic power by 2030, and to achieve the vision of Advanced Indonesia in 204547. Of course, the Islamic Education must not be left behind in its participation in realizing this vision. Hence, the need of transforming Islamic education into Education 4.0 is a strategic national project to accelerate the achievement of this this vision.

Nowedays, Indonesia likely runs one of the biggest Islamic education systems in the world covering all forms of opreation of Islamic teaching and education under the supervision of both the Ministry of Religious Affairs and the Ministry of Education and Cultural Affairs, spreading throughout the archipelago. Incorporating digital technology which belongs to the main elemen of education 4.0 in Islamic education is a necessity to make it accessible more easily and broadly. Furthermore, it will be a key to

${ }^{41}$ Kavita Suri, "Teaching as a Lifelong Process of Learning," September 25, 2016, accessed December 12, 2020, https:/ / www.dailyexcelsior.com.

42 Rafidah Abd Karim et al., "The Use of Mobile Technology in Promoting Education 4.0 for Higher Education," Advanced Journal of Technical and Vocational Education 2, no. 3 (2018): 3439.

43 Ahmad Amri Zainal Adnan, Nek Kamal Yeop Yunus, and Arsalan Mujahid Ghouri, "Does Religiosity Matter in the Era of Industrial Revolution 4.0," Asean Academy of Management Journal 24, no. 2 (2019): 67-77; Ahmad Jamin and Heri Mudra, "Curriculum Development in Islamic Higher Education: Strengthening Characters of Graduates in Facing 4.0 Industrial Revolution and 5.0 Society Era" (Batusangkar International Conference IV, 15 Oktober 2019).

${ }^{44}$ Pavel Sirůček and Zuzana Džbánková, "Quo Vadis, Education 4.0?"

45 Rianto Nurtjahjo, "Pendidikan Indonesia Dan Kesiapan Menuju 4.0," n.d., accessed December 19, 2019, http://bbs.binus.ac.id/ibm/2018/05/.

${ }^{46}$ Eko Risdianto, "Kepemimpinan Dalam Dunia Pendidikan Di Indonesia Di Era Revolusi Industri 4.0," n.d., accessed December 19, 2019, https://www.academia.edu/; Gogot Suharwoto, "Pembelajaran Online Di Tengah Pandemi Covid-19, Tantangan Yang Mendewasakan."

${ }^{47}$ Sigit Suryono, "Making Education 4.0 for Indonesia," Rumah Belajar Pena, Oktober 2018, accessed October 16, 2019, http:// pena.belajar.kemdikbud.go.id/>. 
distributing quality and equitability of the Islamic teaching around this archipelago. An equitable and a quality of education have long been a central problem in the operation of national education which must be addressed immediately ${ }^{48}$. An the same has happened to the Islamic education. An appropriate e-learning model offered by education 4.0 can untangle the geographical limitations to equitability of Islamic education, and the nationa education in general. Using the words of Andaya ${ }^{49}$, transforming into Education 4.0 is a good answer for the Indonesian Islamic education to come.

In line with the Government Regulation of No. 55/2007, by the Islamic education means all efforts to provide religious education as the compulsory subject being designed in the form of subject matters or lectures, that is Islamic religious education, in order to form the students' attitudes, personalities, and skills in practicing the religious teachings in all levels and types of formal (general) education from the elementary up to the university under the supervion of the Ministry of Education and Cultural Affairs.

In the elementary and middle level of education, this subject matter of Islamic religious education is given in the elementary school, the yunior high school, and the senior high school, and the vocational high school as well. Their total number consist of 443,911 units $^{50}$, involving more than 182.000 teachers of Islamic religious education and of 37.655.000 muslim students spreading throughout the archipelago ${ }^{51}$. Whereas, in the (general) university level this lecture is given as the component of Personality Development Lectures (Matakuliah Pengembangan Kepribadian) for the beginning semester students in all departments or study programs. They consist of more than 4.000 units and involving more than 10.000 Islamic lecturers and about more that 1.000.000 muslim students yearly.

Meanwhile, Islamic education run under the supervision of the Ministry of Religion is designed in the form of the operation of Islamic formal education, diniyah (religious nonformal school), and pesantren (the traditional Islamic learning institutions). The Islamic formal education has an equal position with the general education, and developed from the primary and secondary levels to tertiary institutions. In the primary level, they comprise what is called Madrasah Ibtidaiyah (the Islamic elementary school) and Madrasah Tsanawiyah (the Islamic yunior high school), and in the secondary level, there is Madrasah Aliyah (the Islamic senior high school). Totally, there are more than 82,000 units involving more than 331,000 teachers and $8,487,749$ students $^{52}$. In the tertiary level, they are 59 of the state Islamic higher institution which involve more than 18.000 govermental lecturers and 837 private Islamic higher institutions which employ more than 21.000 private lecturers ${ }^{53}$, which enroll more than 1.1 million Islamic students. On the track of diniyah, there are about

48 Atikah Ishmah Winahyu, "Kemenag Dorong Akselerasi Program Guru Besar," Agustus 2020, accessed August 28, 2020, https://mediaindonesia.com-kemenag-dorongakselerasi-program-guru-besar.

49 Jocelyn Andaya, "Education 4.0: Challenges and Directions."

50 Imam, "Ini Jumlah Guru Di Indonesia Tahun 2020," n.d., accessed July 4, 2020, https://bangimam-berbagi.blogspot.com/2020/05/ini-jumlah-guru-di-indonesia-tahun2020.html.

51 Jafar Sodiq Assegaf, "Jumlah Guru Pendidikan Agama Islam Belum Ideal," Mei 2019, accessed August 24, 2020, https://www.solopos.com/jumlah-guru-pendidikan-agama-islambelum-ideal-992945.

52 Imam, “Ini Jumlah Guru Di Indonesia Tahun 2020."

53 Atikah Ishmah Winahyu, "Kemenag Dorong Akselerasi Program Guru Besar." 
about 86.000 madrasah of various levels with about 451.000 teachers and 6.369.000 learners ${ }^{54}$. While, on the pesantren, there are more than 28.000 institutions with 4.200.000 santris (the pesantren learners) spreading throughout the archipelago ${ }^{55}$.

Of course, the Islmic learners are dominated by the digital natives who need the development of a futuristic education approach that matches with the digital environment they live within ${ }^{56}$. Totally, according to the 2017 Survey of the National Central Statistical Agency, the number of them reaches around 88 millions or $33.75 \%$ of the total population of the country. Their growing up in so revolutionized time by technology distinguishes them from the earlier generations in terms of their new and flexible learning habits ${ }^{57}$. As the Indonesia's economy backbone to come ${ }^{58}$, they need a new learning approach which can provides with new skills to compete in this disruptive society confidently ${ }^{59}$. An this ideal can only be reached through bringing them into education $4.0^{60}$.

Though somewhat late for the Southeast Asia region, actually the Indonesian Government has welcome Education 4.0 since 201861. It begun with its supporting the International Symposium on ISODEL (Open, Distance, and e-Learning) with the theme of "Making Education 4.0 for Indonesia" in the end of 201862. This event aimed to provide the opportunity for policy makers, scientists, academics, teachers, researchers and practitioners from all the world to exchange their knowledge, ideas, and experiences to support the Indonesia educational transformation into Education 4.063. As many countries have accomplished, the Government then developed "The $21^{\text {st }}$

${ }^{54}$ Deti Mega Purnamasari, "Jumlah Madrasah Diniyah Takmiliyah RI Besar, Wapres Minta Perlindungan Hak," 2020, accessed July 5, 2020, https://nasional.kompas.com/.

55 Agus Yuliyanto, "Pertumbuhan Pesantren Di Indonesia Dinilai Menakjubkan," 2017, accessed July 5, 2020, https://www.republika.co.id/berita/dunia-islam/islam-nusantara/ $17 / 11 / 30 /$ p088lk396-.

56 Nanang Haroni, “Mengajar Generasi Milenial," 2018, accessed January 9, 2019, https://mediaindonesia.com/; Harry B Santoso, "Akselerasi E-Learning Dan Online Education Di Tanah Air," July 24, 2018, accessed July 18, 2020, https://www.cs.ui.ac.id/index.php/akselerasi-e-learning-dan-online-education-di-tanah-air/.

57 Parag Divan, "Is Education 4.0 an Imperative for Success of 4th Industrial Revolution?," 2017, accessed November 3, 2019, https://medium.com/; Umi Kalsom Kassim and K. Teng Phuah, "Conceptual Study on Enhancement of Education 4.0 from Management Perspective," The 10th InternationalConference on Language, Education, and Innovation. (April 14, 2018).

58 Ali Said, "Statistik Gender Tematik: Profil Generasi Milenial Indonesia," Kementerian Pemberdayaan Perempuan Dan Perlindungan Anak, 2018, https:// www.kemenpppa.go.id/.

59 Ika Rachmawati, "Guru Cerdas Era Revolusi Industri 4.0," April 26, 2019, accessed December 19, 2019, https://www.timesindonesia.co.id/read/; Chea, C. C. and Huan, J. T. J., "Higher Education 4.0: The Possibilities and Challenges."

${ }^{60}$ R. Dhamma, "Filosofi Pendidikan 4.0 Untuk Menghadapi Industri 4.0," January 28, 2019, accessed October 16, 2019, https://www.kompasiana.com/rdp123/; Gerald Ariff, "Indonesia's Higher Education: Staying Relevant in Education 4.0 Era," The Jakarta Post, August 14, 2019, accessed October 10, 2019, https://www.thejakartapost.com/.

${ }^{61}$ Nia Safitri, "Pendidikan Indonesia Menyongsong Era Revolusi 4.0," Kompasiana.Com, November 1, 2019, accessed November 5, 2019, https:/ /www.kompasiana.com/.

62 Yohanes Enggar Harususilo, "Upaya Mendorong Pendidikan 4.0 Indonesia Dari Bali," Kompas.Com, 2018, accessed October 16, 2019, https://edukasi.kompas.com/; Sigit Suryono, "Making Education 4.0 for Indonesia."

63 Zaenal Nur Arifin, "Dukung Pendidikan 4.0 Di Indonesia, SMK Bina Prestasi Bersama Kompas Gramedia Wujudkan Smart Library," March 12, 2018, accessed February 15, 2019, https://bali.tribunnews.com/2018/12/03/. 
Century Learning Framework" emphasizing on how to help the learners develop their ability to find out information from various sources, to think critically and analytically, and to collaborate in problem solving ${ }^{64}$.

For this purpose, the Government has declared the adoption of the Revised 2013 Curriculum, well-known as the national curriculum, which emphases the importance of mastering the $21^{\text {st }}$ Century Skills. Hopefully, this curriculum can answer the criticisms and the problems of the 2013 Curriculum when it was nationally first implemented at public school 65 . Such skills are commonly abbreviated " $4 C^{\prime}$ ", standing for communication, collaboration, critical thinking and problem solving, and creativity and innovation, to enable the learners to strengthen their social and intelektual capasities $^{66}$. For operasional puprposes then they are broken down into four categorical steps. Firstly, ways of thinking include creating, innovating, being critical, problem solving, decision making, and pro-active learning. Secondly, the way to work comprises communicating, collaborating, and working in teams. Thirdly, the way to live as global and local citizens; and fourthly, the devices for developing $21^{\text {st }}$ century skills, namely information technology, digital networks, and literacy ${ }^{67}$.

Seemingly, the fundamental ideas of the Government's transformation into Education 4.0 is the movements the current Minister of Education and Cultural Affairs Mr. Makarim lounched the program of "Merdeka Belajar" (learning in freedom) and "Guru Penggerak" (teacher as an agent of change) in the commemoration of National Teachers' Day in 201968. The most actual is his instruction in the from of the Leaflet of the Ministery of Education and Cultural Affairs No. 4/2020 which regards the operation of education in an emergency period of Covid-19 pandemic via online learning throughout the formal education institution across the country, including the madrasah under the supervision of The Religious Affair Ministry ${ }^{69}$. All these can be a strong foundation for the national education system, including the Islamic education, to accelerate the transformation into the futuristic national education system in a more tangible form: Education 4.070. All elements of the Islamic education sub-system must actively take part in this reform. Otherwise, borrowing the language of Sukartono ${ }^{71}$, the

64 Mohamad Nasir, "Policy for Curriculum and Competencies in the 4th Industrial Revolution (4-IR)" (Education World Forum London, United Kingdom, January 22, 2018); Hamidulloh Ibda, "Penguatan Literasi Baru Pada Guru Madrasah Ibtidaiyah Dalam Menjawab Tantangan Era Revolusi Industri 4.0," Journal of Research and Thought on Islamic Education (JRTIE) 1, no. 1 (September 20, 2018): 1-21.

65 Sukartono, "Revolusi Industri 4.0 Dan Dampaknya Terhadap Pendidikan Di Indonesia," 2018, accessed February 15, 2019, http:/ / semnas.ums.ac.id/.

66 Ibid.; Hendrawan Soetanto, "Rasionalisasi Pengembangan Kurikulum Berorientasi Kkni \& Sn-Dikti Di Era Revolusi Industri," last modified 2019, accessed February 15, 2020, https:/ / docplayer.info/139176599-Rasionalisasi-pengembangan-kurikulum-berorientasi-kknisn-dikti-di-era-revolusi-industri-4-0.html. Indonesia."

67 Sukartono, "Revolusi Industri 4.0 Dan Dampaknya Terhadap Pendidikan Di

68 Liputan6.com, "Mewujudkan Pendidikan 4.0 Jadi Tantangan Besar Mendikbud," liputan6.com, last modified October 23, 2019, accessed February 20, 2020, https://www.liputan6.com/lifestyle/read/4092787/ mewujudkan-pendidikan-40-jaditantangan-besar-mendikbud.

69 Anggi Afriansyah, "Covid-19 Transformasi Pendidikan Dan Berbagai Problemnya," 2020, accessed April 24, 2020, https:/ / kependudukan.lipi.go/.

70 Liputan6.com, "Mewujudkan Pendidikan 4.0 Jadi Tantangan Besar Mendikbud." Indonesia."

71 Sukartono, "Revolusi Industri 4.0 Dan Dampaknya Terhadap Pendidikan Di 
Islamic education will paralyze because of the rapid change that must be born in the disruptive era.

As an integral part of the national education system, the Islamic education is the priceless asset of the nation which will determine the picture of national education and what the Indonesia's young generation will look like in the future. Thus, the strategic position of the Islamic education cannot be ignored anymore because in fact the Islamic education is none other than the identity of the national education itself. It means that the progress of the Islamic education is the progress of the national education itself and the decline of the Islamic education reflects the decline of the national education as well. It is the obligation of all elements of the nation to continue to maintain and develop it optimally and sustainably.

Transformation into Education 4.0 is a good solution for the Islamic education and the national education in general to face the demands of change caused by both the Industrial Revolution 4.0 and the unpresendented non-natural disasters, such as the Covid-19 pandemic, which has paralyzed conventional learning activities around the world. Philosofically, the Islamic education concept of 'cradle-to-grave' for lifelong learning gains prominence in the transformation into Education 4.0 in the precent day world of education and work environment. Pragmatically, this transformation will strengthen the endurnce of the Islamic education and the national education in the Post-Pandemic era and in their quick adaption to find out the innovative ways to educate the students in the disruptive era, and in the attempt to realize the Indonesia golden generation in 2045 in general.

\section{G. Challenges}

The transformation of Islamic education into education 4.0 is a great national work that should involve many parties, including the government which holds an authority in education. The challenges are very broad. For the practical purposes, however, they can be summarized into five areas. Firstly, the curriculum challenges. According to some education observers, the today Islamic curriculum is still inadequate $^{72}$. Seemingly, Education 4.0 does not mention the importance of religion/spirituality at all since it derives from and developes in the Western society in which the issue of religion/spirituality is not the public concern. But, its application in multicultural countries, like Indonesia, it is entirely up to the countries or communities concerned $^{73}$. This means that it is not merely about how the Indonesia Islamic education deals with "man, machine, and technology desolved, but also with the ability to formulate his own vision in line with the vision of Education 4.0 for the next Indonesia good muslim. Seemingly, this is the essence of this challenge: conseptualing the Islamic education 4.0 for the next Indonesia muslim generation.

72 J. Musfah, "Kurikulum PAI," 2019, accessed July 6, 2020, https://www.uinjkt.ac.id/id/kurikulum-pai/; Heny Kusmawati and Anista Ika Surachman, "Glokalisasi Kurikulum Pendidikan Agama Islam Madrasah Aliyah Keagamaan Di Era Revolusi Industri 4.0," Jurnal Ilmiah Pendidikan Dasar 6, no. 2 (August 24, 2019): 98-115; Adun Priyanto, "Pendidikan Islam dalam Era Revolusi Industri 4.0," J-PAI: Jurnal Pendidikan Agama Islam 6, no. 2 (June 12, 2020), accessed May 5, 2021, http://ejournal.uinmalang.ac.id/index.php/jpai/article/view/9072.

${ }^{73}$ Ahmad Amri Zainal Adnan, Nek Kamal Yeop Yunus, and Arsalan Mujahid Ghouri, "Does Religiosity Matter in the Era of Industrial Revolution 4.0"; Ahmad Jamin and Heri Mudra, "Curriculum Development in Islamic Higher Education: Strengthening Characters of Graduates in Facing 4.0 Industrial Revolution and 5.0 Society Era." 
To answer these challenges, borrowing the language of Masters, the Indonesia Islamic education should immediately redesign its curriculum to adapt the vision of education 4.0 to prepare the Muslim students for life and work in the 21st century. It means that the Islamic curriculum must provide with the specified skills including the skills in communicating, creating, using technologies, working in teams and problem solving. This curriculum must also give its space for developing the students' deep understandings of essential disciplinary concepts and principles and their ability to apply these understandings to complex, engaging real-world problems. In short, on the basis of the dynamic teachings of Islam, such an Islamic curriculum must equip students with the new skills for anticipating and living in the rapidly changing world, including the world of work ${ }^{74}$.

This curriculum should teach the real and living Islam deriving from the mainstream Sunni school of Islam devoted by the majority of the Indonesian people and of the Southeast Asian people in general which openly respects the diversity of Islamic doctrines and religions within. It means that the Islamic religious education in the national curriculum is neither "Islam" of the fundamentalist/radicalist Muslim which has been stripped off from all its richness of traditional legacy, as the salafistwahabist being promoted, which Tibi ${ }^{75}$ regarded as being afraid of encountering the modernity; nor "Islam" of the liberalist Muslim, that is "Islam" dominated by free thinking and an attempt to re-question the religious principles devoted by majority of Sunny ulama (ijmak), or what is often referred to "the rationalist/sceptic scism of Islam"76. In other words, it belongs to "moderate Islam" which is expected to be the connecting and synergizing factor in understanding the secular achievement and religious traditions for the glory of nation and the the mercy of human beings in general.

Secondly, pedagogical challenges. Pedagogy deals with how to enable the best way to achieve learning. Successful pedagogy requires the teacher to understand how students learn then design and deliver course materials, and mentor students appropriately, so that knowledge and skills are passed on ${ }^{77}$. It is well known, education 4.0 leads to a very fundamental paradigmatic shift where learning is emphasized on personalised learning, and teaching-learning process is flexible in the sense that the students have not to be in face-to-face in the classroom, but I can can take place in an elearning environment which requires a different approach to pedagogy especially in areas such as individual and group interaction and online assessment. Flexible pedagogy is a prerequisite to face and create this new teaching-learning environment ${ }^{78}$. Unfortunately, this flexible pedagogy is still in a dream. Because the national education

74 Dede Rosyada and Andriyani Andriyani, "Challenges of Islamic Religious Education Due to The Implementation of 4.0 Industrial Era," 2020, accessed May 5, 2021, https://eudl.eu/doi/10.4108/eai.30-9-2019.2291133.

75 Bassam Tibi, The Challenge of Fundamentalism, n.d., accessed May 5, 2021, https:/ / www.ucpress.edu/book/9780520236905/the-challenge-of-fundamentalism.

76 Admin, "Islam Liberal: Gerakan Transnasional Yang Dinaturalisasikan," INSISTS, September 18, 2019, accessed July 9, 2020, https://insists.id/islamliberal-gerakantransnasional/.

77 Nurul Islam, Martin Beer, and Frances Slack, "E-Learning Challenges Faced by Academics in Higher Education: A Literature Review," Journal of Education and Training Studies 3, no. 5 (July 13, 2015): 102-112.

78 Rosyada and Andriyani, "Challenges of Islamic Religious Education Due to The Implementation of 4.0 Industrial Era." 
system itself, in which the Islamic education is within, regards the opposite so that make it difficult to keep up with the dynamics of fast changing times ${ }^{79}$.

Certainly, this is a serious challenge because it relates to the teachers' understanding of various different teaching methods and various learning styles of the students which will implicate on how to consider the learning outcomes to accommodate their learning environment. Education 4.0 provides the students with an appropriate place for a face-to-face learning in classroom and an online form as well. Online learning is different from a classroom learning. It means that teachers need to think critically about what content is included and excluded when they move courses online. Redesigning a conventional syllabus to suit online learning platforms affords teachers an opportunity to revisit the learning outcomes of their course and review whether all of the content aligns with them ${ }^{80}$. Authomatically, this will affect the shift in the role of the teacher from "the teacher as a knowledge expert" to a facilitator whose task is to help learners develop their existing skills in such a flexible learning situation to enable them to become independent and creative learners and critical thinkers ${ }^{81}$.

Thirdly, the challenge of developing an efficient and sustainable learning management system. It means that, borrowing the language of Puncreobutr ${ }^{82}$, leveraging technology and digitalization in the teaching and learning management when must be immediatly developed when the Islamic education will take advantage of Education 4.0. Because only this approach will provide all students with equal access and opportunities to interact with teachers and their friends without any obstacles and intrusions that could interfere with the interaction process. For this purpose, education experts said that blended learning can be a suitable option as an approach to learning $4.0^{83}$.

There are many different definitions being put forward for blended learning ${ }^{84}$. For a practical purpose, however, blended learning is understood as a flexible way of accomplishing the course which combines the main features of both traditional teaching approach and ICT supported teaching to enable teachers to employ a variety of teaching strategies in the classroom ${ }^{85}$ It includes the use of web studies, virtual

79 Andhika Prasetyo, "Sistem Pendidikan Harus Fleksibel," last modified November 29, 2019, accessed September 2, 2020, https://mediaindonesia.com/humaniora/274505/sistempendidikan-harus-fleksibel.

80 David Reiersgord, "Online Education during the Pandemic: The Challenges and Opportunities," Daily Maverick, last modified April 2, 2020, accessed July 13, 2020, https://www.dailymaverick.co.za/article/2020-04-03-online-education-during-the-pandemicthe-challenges-and-opportunities/.

81 Peter Fisk, "Education 4.0"; Matthew Lynch and Ido Yerushalmi, "Six Ways to Get Your School on the Education 4.0 Train"; Irma Kunnari, Ho Thi Hanh Tien, and Thanh-Lam Nguyen, "Rethinking Learning Towards Education 4.0."

82 Vichian Puncreobutr, "Education 4.0: New Challenge of Learning."

83 Wasis D. Dwiyogo, "Pembelajaran Berbasis Blended Learning - Design Blended Learning and Online Education," 2018, accessed August 4, 2020, https://bl.curriculumdesignhe.eu/pembelajaran-berbasis-blended-learning/; Agus Setiawan, "Implementation of Islamic Education Study Program Learning Based on Blended Learning in the Industrial Era 4.0 at IAIN Samarinda," Dinamika Ilmu: Jurnal Pendidikan 19, no. 2 (December 15, 2019): 305-321.

${ }^{84}$ Helen Partridge et al., Good Practice Report: Blended Learning. (Strawberry Hills NSW: Australian Learning and Teaching Council (ALTC), 2011).

85 Dr. Lalima and Kiran Lata Dangwal, "Blended Learning: An Innovative Approach," Universal Journal of Educational Research 5, no. 1 (January 2017): 129-136. 
classrooms, email, online activities, service learning and journal activities ${ }^{86}$. In the language of Dwiyogo ${ }^{87}$, the implementation of blanded learning enables the teachers and students to work together to improve the quality of learning by creating the opportunity to make the right learning experiences, through the right learning processes, in the right places for every student 88 .

There are many models and compositions of blended learning that can be developed 89 . Determining which to operate requires a number of requirements to fulfill. Some of them include well trained teachers with wider outlook and positive approach towards change, students with good access to internet at their private computers, flexibility of the schooling system, well aware and fully agreed parent of this innovative approach to teaching and learning, and completely equipped schools with computer lab and the internet facility ${ }^{90}$.

Fourthly, the availability of infrastructure challenge, especially the internet and the electricity network. Without this infrastructure, it is impossible for the Islamic education to transform into Education 4.0. Regarding the access to electricity, the conditions are relatively adequate. According to The Ministery of Energy and Human Resource Affairs, till the beginning of 2020, of the total 83,436 villages, there are 83,003 villages having been electrified. Meanwhile, the rest have no electricity, mostly in Papua (324 villages), West Papua (103 villages), the East Nusa Tenggara and Maluku (5 villages). It is endeavored that in 2020 all villages will have been completely electrified $^{91}$. In terms of the availability of internet network, the condition can be the opposite. It is because that not all areas, especially in rural areas, can be reached by the internet ${ }^{92}$. According to Novianda ${ }^{93}$, internet infrastructure is currently still focused on Java and urban areas, up to $71-72 \%$; while, the rural areas get only $42-48 \%$.

Seemingly, this limitation causes the Islamic education suffer the most because most the Islamic education institutions, especially madrasah, are privately operated both in rural Java and outside Java. The Ministery of Education and Cultural Affairs registered that there were 8,552 unelectrified schools and 42,159 schools which did not

86 Prof Ian Nell, "Blended Learning: Innovation in the Teaching of Practical Theology to Undergraduate Students. OJAA, 2015" (n.d.), accessed May 5, 2021, https:/ / www.academia.edu/13095807/Blended_learning_Innovation_in_the_teaching_of_prac tical_theology_to_undergraduate_students_OJAA_2015.

87 Wasis D. Dwiyogo, "Pembelajaran Berbasis Blended Learning - Design Blended Learning and Online Education."

88 Ibid.

89 A. Bryan and Kseniya Volchenkova, “Blended Learning: Definition, Models, Implications For Higher Education" 8 (January 1, 2016): 24-30.

90 Lalima and Lata Dangwal, "Blended Learning."

91 Rina Anggraeni, "Tersisa 433 Desa Belum Teraliri Listrik, Target Rampung Tahun Ini," SINDOnews.com, last modified April 3, 2020, accessed August 9, 2020, https:/ / ekbis.sindonews.com/ berita/1577956/34/tersisa-433-desa-belum-teraliri-listrik-targetrampung-tahun-ini.

92 Harry B Santoso, "Akselerasi E-Learning Dan Online Education Di Tanah Air"; Rivco Tololiu, "DPR Desak Kemendikbud dan Kominfo Segera Benahi Jaringan Internet," SINDOMANADO, June 18, 2020, accessed August 7, 2020, https:/ / sindomanado.com/2020/06/18/28462/.

93 Anesthesia Novianda, "Menjembatani Kesenjangan Digital dalam Pendidikan," detiknews, accessed July 18, 2020, https://news.detik.com/kolom/d-5087800/menjembatanikesenjangan-digital-dalam-pendidikan. 
have internet access ${ }^{94}$. Whereas the Minstery of Religious Affaits noted that there were tens of thousands of madrasas without electricity and access to the internet, especially in the interior areas of East and West Java. According to Republika, there are 3,193 madrasas out of a total of 20,293 madrasas in East Java, and 2,684 madrasas out of a total of 15,641 in West Java have no internet access. While according to the Nahdlatul Ulama which claims to have around 48 thousand madrassas, only one third of them can be registered due to lack of internet access and electricity 95 . On the other hand, there are still gaps between the have and the have not in the ability to access the internet ${ }^{96}$. Obviously, this gap can create disparities that are detrimental to the resilience and the future of the Islamic education itself.

The fifth is related to cultural challenge. As Islam et al. ${ }^{97}$ said, everyone has their own learning style along with their cultural influences. This also applies to Muslim students who are raised in a distinctive Islamic educational cultural environment. This means that it is not easy for the Islamic education to transform into education 4.0. Past experience showed that the modernization of Islamic education in Indonesia and in the muslim countries did not always take place smoothly because of the strength of resistance to it. The same can take place again when it is dealing with education 4.0. Because it will lead to a fundamental change in the most basic aspect of the Islamic education tradition, namely the reduced role of traditional educational institutions as the center for transmitting (religious) knowledge which will be possibly replaced by "virtual classes" in education 4.0. In fact, their existence in the Islamic education tradition is considered sacred, and their role as the center of spreading knowledge is irreplaceable ${ }^{98}$.

Moreover, the tradition of Islamic instruction so far only recognizes the face to face learning model which requires each student to meet their teachers directly (musyafahah $)^{99}$. Like learning institution, in this tradition teachers are considered as the only authoritative sources of learning and the (religious) knowledge transmitter ${ }^{100}$, and as a place for the learners to rely on memorization, public speaking, and oral examinations ${ }^{101}$. Furthermore, Engineer ${ }^{102}$ stated, they are also recognized nothing but

94 Ni Putu Maryati Saputri, “Antisipasi Pemerintah Pada Pendidikan Di Indonesia Saat Pandemi - Beritabali.Com," https:/ / www.opini.beritabali.com/read/2020/08/07/202008070007/antisipasi-pemerintahpada-pendidikan-di-indonesia-saat-pandemi.

95 Nashih Nashrullah, "PBNU Akui Nihil Internet Dan Listrik Kendala Data Madrasah," 2020, accessed August 7, 2020, https://www.msn.com/id-id/news/nasional/pbnu-akui-nihilinternet-dan-listrik-kendala-data-madrasah/ar-BB16u5jN.

96 Redaksi, "Kesenjangan Akses Internet Pengaruhi Kualitas Pendidikan Warga," SaifulMujani, August 18, 2020, accessed August 18, 2020, https://saifulmujani.com/kesenjangan-akses-internet-pengaruhi-kualitas-pendidikan-warga/. Education."

97 Islam, Beer, and Slack, "E-Learning Challenges Faced by Academics in Higher

98 Ashgar Ali Engineer, "Islam and Contemporary Issues - Irénées," accessed July 9, 2020, https://www.irenees.net/bdf_fiche-defis-252_en.html.

99 Ukkasyah Abdul Qohhar, "Pembelajaran Secara Online Dari Segi Agama Islam keluhkesah.com," n.d., accessed July 31, 2020, https://keluhkesah.com/pembelajaran-secaraonline-dari-segi-agama-islam/.

100 N. Syam, "Pendidikan Islam Dalam Tantangan Era Industri 4.0," n.d., accessed September 8, 2018, https:// kemenag.go.id/.

101 T. Alfaham, "World Muslim Communities Council Organises Virtual Conference on 27th June," 2020, accessed June 24, 2020, https:/ / wam.ae/en/details/1395302850889.

102 Ashgar Ali Engineer, "Islam and Contemporary Issues - Irénées." 
centres of acknowledgement rather than of knowledge. In such a model of learning no new knowledge can be produced, but only acknowledged traditions can continue. They cannot become the centers of intellectual excellence but centers of traditional knowledge.

Resistance of to this change may comes in many forms, but one of the commonest in the ground is, using the language of Nagel103, the feeling of "comfort with the status quo", especially for the senior religious teachers. This condition is understandable. Beside unfamiliar with this new learning approach, they had never been provided with the teaching method 4.0 when they were in their teacher training before. Unfortunately, there are some of them always feeling "old enough" to keep up with learning about new technology ${ }^{104}$. Moreover, the new learning method is often considered as being difficult for the learners and their parents who were mostly weak in ICT use and to get internet access ${ }^{105}$. The most serious appears in the form of ignorance of most Islamic higher learning institutions themselves for their assumption that ICT-based learning does not belong to the Islamic educational tradition ${ }^{106}$. In fact, as pointed out by the "World Muslim Communities Council", this learning approach can reduce the function of Islamic education itself107.

Such a cultural resistance can make it difficult for the continuation of the Islamic education operation in this era because, like or dislike, it has become an integral part of global reality of education, who cannot avoid the ongoing changes, including ICTbased learning ${ }^{108}$. The initiation of the Ministry of Religious Affairs, for example, to launch a learning platform through e-learning Madrasah ${ }^{109}$ recently will encourage the acceleration of the Islamic education in accepting and adapting to the demands of the transformation of education 4.0. Likewise, breakthroughs made by some Islamic higher institutions, such as the State Institute for Islamic Studies of Jember (http://lms.iain-jember.ac.id/) as well as the pesantren circle, such as the well-known Pesantren Tebuireng of the East Java (https://smpawhtebuireng.sch.id) can trigger other Islamic learning institutions to adapt themselves to the demands of and the changes occuring in this digital era. Actions usually speak louder than words.

\section{H. Conclusion}

The unpresendented presence of Covid 19 Pandamic in the beginning of 2020 has hit the world of education around the world, including Indonesia's Islamic Education, so badly that requires it to immediately recover in order to free itself from the educational crisis, and be able to adapt to the new demands of the global education in

103 By David Nagel, "6 Technology Challenges Facing Education -," THE Journal, accessed July 15, 2020, https://thejournal.com/articles/2013/06/04/6-technology-challenges-facingeducation.aspx.

104 sutiono, "11 Kelebihan dan Kekurangan E Learning dalam Pembelaran," DosenIT.com, last modified August 19, 2017, accessed July 31, 2020, https://dosenit.com/kuliah-it/teknologiinformasi/kelebihan-dan-kekurangan-e-learning.

105 Moh. Fail, “Tiga Hambatan Pembelajaran Daring di Desa," Shipping Line Indonesia, July 14, 2020, accessed July 18, 2020, https://shippinglineindonesia.com/tiga-hambatanpembelajaran-daring-di-desa/.

106 N. Syam, "Pendidikan Islam Dalam Tantangan Era Industri 4.0."

107 T. Alfaham, "World Muslim Communities Council Organises Virtual Conference on 27th June."

${ }^{108}$ Ibid.

109 Penulis Admin Ayo Madrasah, "Ayo Madrasah: E-Learning Madrasah, Gratis Dari Kemenag," Ayo Madrasah, n.d., accessed August 19, 2020, https://www.ayomadrasah.id/2020/03/e-learning-madrasah-gratis-dari-kemenag.html. 
the era of Industry 4.0. The Indonesia's Islamic education, which is one of the largest Islamic education systems in the world, must be at the forefront of this endeavor. If not, the so-called education lag will affect the profile of the Muslims generations to come. To avoid this, it is necessary for the Indonesia's Islamic Education to make a fundamental leapforging with adaptation to Education 4.0. With the physical and nonphysical infrastructure that the government has been currently developing, the ability of the Indonesia's Islamic education to transform itself into this direction is not difficult to realize. Philosophically, the Islamic education's concept of 'cradle-to-grave' learning for lifelong learning gets prominence in the Education 4.0. In addition, the breakthroughs of some Indonesia's Islamic education institutions to innovate in using online learning during the pandemic will facilitate and encourage the adaptation of the futuristic learning process in the Islamic education. There are many challenges both internal and external faced by the Indonesia's Islamic Education for this change. Crearly, the willingness of the supporting community to change for the better and collaborating between stakeholders is the main key to success in this field.

\section{REFERENCES}

Admin. "Islam Liberal: Gerakan Transnasional Yang Dinaturalisasikan." INSISTS, September 18, 2019. Accessed July 9, 2020. https://insists.id/islamliberalgerakan-transnasional/.

Agus Yuliyanto. "Pertumbuhan Pesantren Di Indonesia Dinilai Menakjubkan," 2017. Accessed July 5, 2020. https://www.republika.co.id/berita/dunia-islam/islamnusantara/ 17/11/30/p0881k396-.

Ahmad Amri Zainal Adnan, Nek Kamal Yeop Yunus, and Arsalan Mujahid Ghouri. "Does Religiosity Matter in the Era of Industrial Revolution 4.0." Asean Academy of Management Journal 24, no. 2 (2019): 67-77.

Ahmad Jamin and Heri Mudra. "Curriculum Development in Islamic Higher Education: Strengthening Characters of Graduates in Facing 4.0 Industrial Revolution and 5.0 Society Era." Batusangkar International Conference IV, 15 Oktober 2019.

Ali Said. "Statistik Gender Tematik: Profil Generasi Milenial Indonesia." Kementerian Pemberdayaan Perempuan Dan Perlindungan Anak, 2018. https://www.kemenpppa.go.id/.

Anas Abdelrazeq, Daniela Janssen, Christian Tummel, Anja Simone Richert, and Sabina Jeschke. "Teacher 4.0: Requirements of The Teacher of The Future in Context of The Fourth Industrial Revolution." ICERI, Seville Nov, 16th - Nov, 14th (2016).

Andhika Prasetyo. "Sistem Pendidikan Harus Fleksibel." Last modified November 29, $2019 . \quad$ Accessed September 2, 2020. https://mediaindonesia.com/humaniora/274505/sistem-pendidikan-harusfleksibel.

Anealka Aziz Hussin. "Education 4.0 Made Simple: Ideas for Teaching." International Journal of Education \& Literacy Studies 6, no. 3 (2017): 92-98.

Anggi Afriansyah. "Covid-19 Transformasi Pendidikan Dan Berbagai Problemnya," 2020. Accessed April 24, 2020. https://kependudukan.lipi.go/.

Ashgar Ali Engineer. "Islam and Contemporary Issues - Irénées." Accessed July 9, 2020. https://www.irenees.net/bdf_fiche-defis-252_en.html. 
Atikah Ishmah Winahyu. "Kemenag Dorong Akselerasi Program Guru Besar," Agustus 2020. Accessed August 28, 2020. https://mediaindonesia.com-kemenagdorong-akselerasi-program-guru-besar.

Bassam Tibi. The Challenge of Fundamentalism, n.d. Accessed May 5, 2021. https://www.ucpress.edu/book/9780520236905/the-challenge-offundamentalism.

Bryan, A., and Kseniya Volchenkova. "Blended Learning: Definition, Models, Implications For Higher Education" 8 (January 1, 2016): 24-30.

Chea, C. C. and Huan, J. T. J. "Higher Education 4.0: The Possibilities and Challenges." Journal of Social Sciences and Humanities 5, no. 2 (2019): 81-85.

Delipiter Lase. “Pendidikan Di Era Revolusi Industri 4.0." JCTES 1, no. 1 (2019): 28-43.

Deti Mega Purnamasari. “Jumlah Madrasah Diniyah Takmiliyah RI Besar, Wapres Minta Perlindungan Hak," 2020. Accessed July 5, 2020. https://nasional.kompas.com/.

Eko Risdianto. "Kepemimpinan Dalam Dunia Pendidikan Di Indonesia Di Era Revolusi Industri 4.0," n.d. Accessed December 19, 2019. https://www.academia.edu/.

Ethan Dunwill. " 4 Changes That Will Shape the Classroom of the Future: Making Education Fully Technological," n.d. Accessed October 16, 2019. https:// elearningindustry.com/.

FICCI-EY, ed. "Leapfrogging to Education 4.0: Learner at the Core, India." Federation of Indian Chambers of Commerce and Industry, 2017.

Gerald Ariff. "Indonesia's Higher Education: Staying Relevant in Education 4.0 Era." The Jakarta Post, August 14, 2019. Accessed October 10, 2019. https://www.thejakartapost.com/.

Glaucio Messias, Ueliton Rodrigues, Luis Braga, Walter Nakamura, Bruna Ferreira, Alex Paiva, and Natasha Valentim. "Education 4.0 and 21st Century Skills: A Case Study with Robotics Activities in Classroom." Anais do XXIX Simpósio Brasileiro de Informática na Educação (SBIE) (2018).

Gogot Suharwoto. "Pembelajaran Online Di Tengah Pandemi Covid-19, Tantangan Yang Mendewasakan," April 2, 2020. Accessed June 23, 2020. www.timesindonesia.com.

Gonzalo Fuentes. "The COVID-19 Pandemic Has Changed Education Forever," April 29, 2020. Accessed September 19, 2020. https://www.weforum.org/.

Harry B Santoso. "Akselerasi E-Learning Dan Online Education Di Tanah Air," July 24, 2018. Accessed July 18, 2020. https://www.cs.ui.ac.id/index.php/akselerasi-elearning-dan-online-education-di-tanah-air/.

Hendrawan Soetanto. "Rasionalisasi Pengembangan Kurikulum Berorientasi Kkni \& Sn-Dikti Di Era Revolusi Industri." Last modified 2019. Accessed February 15, 2020. https://docplayer.info/139176599-Rasionalisasi-pengembangankurikulum-berorientasi-kkni-sn-dikti-di-era-revolusi-industri-4-0.html.

Hoekman, Katherine. "The Teacher as Facilitator for Independent Learning." Gifted (1996). Accessed December 12, 2020. https:// www.academia.edu/2627694/The_teacher_as_facilitator_for_independe nt_learning.

Ibda, Hamidulloh. "Penguatan Literasi Baru Pada Guru Madrasah Ibtidaiyah Dalam Menjawab Tantangan Era Revolusi Industri 4.0." Journal of Research and Thought on Islamic Education (JRTIE) 1, no. 1 (September 20, 2018): 1-21.

Ika Rachmawati. "Guru Cerdas Era Revolusi Industri 4.0," April 26, 2019. Accessed December 19, 2019. https://www.timesindonesia.co.id/read/. 
Imam. “Ini Jumlah Guru Di Indonesia Tahun 2020," n.d. Accessed July 4, 2020. https:// bangimam-berbagi.blogspot.com/2020/05/ini-jumlah-guru-diindonesia-tahun-2020.html.

Irma Kunnari, Ho Thi Hanh Tien, and Thanh-Lam Nguyen. "Rethinking Learning Towards Education 4.0." HAMK Unlimited Journal, n.d. Accessed January 21, 2020. https:/ / unlimited.hamk.fi/.

Islam, Nurul, Martin Beer, and Frances Slack. "E-Learning Challenges Faced by Academics in Higher Education: A Literature Review." Journal of Education and Training Studies 3, no. 5 (July 13, 2015): 102-112.

J. Musfah. "Kurikulum PAI," 2019. Accessed July 6, 2020. https://www.uinjkt.ac.id/id/kurikulum-pai/.

Jafar Sodiq Assegaf. “Jumlah Guru Pendidikan Agama Islam Belum Ideal," Mei 2019. Accessed August 24, 2020. https://www.solopos.com/jumlah-guru-pendidikanagama-islam-belum-ideal-992945.

Jaime Saavedra. "Educational Challenges and Opportunities of the Coronavirus (COVID-19) Pandemic," March 30, 2020. Accessed September 19, 2020. blogs.worldbank.org/education/.

Jaspreet Bindra. "Education in the Post-Pandemic World Cannot Be the Same Again," June 25, 2020. Accessed September 19, 2020. https://www.livemint.com/.

Jean Marc Bernard, Brahima Coulibaly, and Rebecca Winthroup. "Education Is Crucial to Africa's COVID-19 Response," June 4, 2020. Accessed September 27, 2020. https://www.brookings.edu/.

Jocelyn Andaya. "Education 4.0: Challenges and Directions," November 28, 2018. Accessed October 10, 2019. http:/ / patef-update.org/.

Jujun S. Suria Sumantri. Penelitian Ilmiah, Kefilsafatan, dan Keagamaan: Mencari Paradigma Kebersamaan" in Mastuhu and Deden Ridwan, Tradisi baru penelitian agama Islam: tinjauan antardisiplin ilmu. Bandung: Nuansa, 2001.

Kavita Suri. "Teaching as a Lifelong Process of Learning," September 25, 2016. Accessed December 12, 2020. https:/ / www.dailyexcelsior.com.

Kusmawati, Heny, and Anista Ika Surachman. "Glokalisasi Kurikulum Pendidikan Agama Islam Madrasah Aliyah Keagamaan Di Era Revolusi Industri 4.0." Jurnal Ilmiah Pendidikan Dasar 6, no. 2 (August 24, 2019): 98-115.

Lalima, Dr., and Kiran Lata Dangwal. "Blended Learning: An Innovative Approach." Universal Journal of Educational Research 5, no. 1 (January 2017): 129-136.

Lily Nyariki. "Africa Supports Reading and Learning during the COVID-19 Pandemic," April 23, 2020. Accessed September 27, 2020. https://www.globalpartnership.org/.

Liputan6.com. "Mewujudkan Pendidikan 4.0 Jadi Tantangan Besar Mendikbud." liputan6.com. Last modified October 23, 2019. Accessed February 20, 2020. https:// www.liputan6.com/lifestyle/read/4092787/ mewujudkan-pendidikan40-jadi-tantangan-besar-mendikbud.

Lisa Chesser. "Modern Trends in Education: 50 Different Approaches to Learning," March 5, 2019. Accessed May 7, 2020. www.teachthought.com.

Madrasah, Penulis Admin Ayo. "Ayo Madrasah: E-Learning Madrasah, Gratis Dari Kemenag." Ayo Madrasah, n.d. Accessed August 19, 2020. https://www.ayomadrasah.id/2020/03/e-learning-madrasah-gratis-darikemenag.html.

Manisha Sharma. "Teacher in a Digital Era." Global Journal of Computer Science and Technology (G) 17, no. 3 (2017): 11-14. 
Matthew Lynch and Ido Yerushalmi. "Six Ways to Get Your School on the Education 4.0 Train," June 7, 2018. Accessed January 23, 2020. http://blogs.edweek.org/.

Meylinda Maria, Faaizah Shahbodin, and Naim Che Pee. "Malaysian Higher Education System towards Industry 4.0 - Current Trends Overview." AIP Conference Proceedings 2016 (n.d.).

Moh. Fail. "Tiga Hambatan Pembelajaran Daring di Desa." Shipping Line Indonesia, July 14, 2020. Accessed July 18, 2020. https://shippinglineindonesia.com/tigahambatan-pembelajaran-daring-di-desa/.

Mohamad Nasir. "Policy for Curriculum and Competencies in the 4th Industrial Revolution (4-IR)." Education World Forum London, United Kingdom, January 22, 2018.

N. Syam. "Pendidikan Islam Dalam Tantangan Era Industri 4.0," n.d. Accessed September 8, 2018. https:// kemenag.go.id/.

Nagel, By David. "6 Technology Challenges Facing Education -." THE Journal. Accessed July 15, 2020. https://thejournal.com/articles/2013/06/04/6technology-challenges-facing-education.aspx.

Nanang Haroni. "Mengajar Generasi Milenial," 2018. Accessed January 9, 2019. https://mediaindonesia.com/.

Nashih Nashrullah. "PBNU Akui Nihil Internet Dan Listrik Kendala Data Madrasah," 2020. Accessed August 7, 2020. https://www.msn.com/idid/news/nasional/pbnu-akui-nihil-internet-dan-listrik-kendala-datamadrasah/ar-BB16u5jN.

Nell, Prof Ian. "Blended Learning: Innovation in the Teaching of Practical Theology to Undergraduate Students. OJAA, 2015" (n.d.). Accessed May 5, 2021. https://www.academia.edu/13095807/Blended_learning_Innovation_in_the_te aching_of_practical_theology_to_undergraduate_students_OJAA_2015.

Ni Putu Maryati Saputri. "Antisipasi Pemerintah Pada Pendidikan Di Indonesia Saat Pandemi - Beritabali.Com." Accessed August 7, 2020. https://www.opini.beritabali.com/read/2020/08/07/202008070007/antisipasipemerintah-pada-pendidikan-di-indonesia-saat-pandemi.

Nia Safitri. "Pendidikan Indonesia Menyongsong Era Revolusi 4.0." Kompasiana.Com, November 1, 2019. Accessed November 5, 2019. https://www.kompasiana.com/.

Novianda, Anesthesia. "Menjembatani Kesenjangan Digital dalam Pendidikan." detiknews. Accessed July 18, 2020. https://news.detik.com/kolom/d5087800/menjembatani-kesenjangan-digital-dalam-pendidikan.

Ollia Horton. "Covid-19 Is Hampering Access to Education Particularly in Africa," September 19, 2020. Accessed September 27, 2020. https://www.rfi.fr/en/international/20200909.

Parag Divan. "Is Education 4.0 an Imperative for Success of 4 th Industrial Revolution?," 2017. Accessed November 3, 2019. https://medium.com/.

Partridge, Helen, Deborah Ponting, Meryl McCay, and Australian Learning and Teaching Council (ALTC). Good Practice Report: Blended Learning. Strawberry Hills NSW: Australian Learning and Teaching Council (ALTC), 2011.

Pavel Sirůček and Zuzana Džbánková. "Quo Vadis, Education 4.0?" The 12th International Days of Statistics and Economics, Prague. (September 6, 2018).

Peter Fisk. “Education 4.0," 2017. Accessed January 24, 2020. https://www.thegeniusworks.com/. 
Priyanto, Adun. "Pendidikan Islam dalam Era Revolusi Industri 4.0." J-PAI: Jurnal Pendidikan Agama Islam 6, no. 2 (June 12, 2020). Accessed May 5, 2021. http:/ / ejournal.uin-malang.ac.id/index.php/jpai/article/view/9072.

R. Dhamma. "Filosofi Pendidikan 4.0 Untuk Menghadapi Industri 4.0," January 28, 2019. Accessed October 16, 2019. https:/ / www.kompasiana.com/rdp123/.

Rafidah Abd Karim, Abdul Ghani Bin Abu, Airil Haimi Mohd Adnan, and Astri Dwi Jayanti Suhandoko. "The Use of Mobile Technology in Promoting Education 4.0 for Higher Education." Advanced Journal of Technical and Vocational Education 2, no. 3 (2018): 34-39.

Rasika Lawrence, Lim Fung Ching, and Haslinda Abdullah. "Strengths and Weaknesses of Education 4.0 in the Higher Education Institution." International Journal of Innovative Technology and Exploring Engineering (IJITEE) 9 (December 23, 2019): 511-518.

Redaksi. "Kesenjangan Akses Internet Pengaruhi Kualitas Pendidikan Warga." SaifulMujani, August 18, 2020. Accessed August 18, 2020. https:// saifulmujani.com/kesenjangan-akses-internet-pengaruhi-kualitaspendidikan-warga/.

Reiersgord, David. "Online Education during the Pandemic: The Challenges and Opportunities." Daily Maverick. Last modified April 2, 2020. Accessed July 13, 2020. https://www.dailymaverick.co.za/article/2020-04-03-online-educationduring-the-pandemic-the-challenges-and-opportunities/.

Rianto Nurtjahjo. "Pendidikan Indonesia Dan Kesiapan Menuju 4.0," n.d. Accessed December 19, 2019. http://bbs.binus.ac.id/ibm/2018/05/.

Rina Anggraeni. "Tersisa 433 Desa Belum Teraliri Listrik, Target Rampung Tahun Ini." SINDOnews.com. Last modified April 3, 2020. Accessed August 9, 2020. https:// ekbis.sindonews.com/berita/1577956/34/tersisa-433-desa-belumteraliri-listrik-target-rampung-tahun-ini.

Robin T. Bye. "The Teacher as a Facilitator for Learning Flipped Classroom in a Master's Course on Artificial Intelligence," Agustus 2017. www.researchgate.net/.

Rosyada, Dede, and Andriyani Andriyani. "Challenges of Islamic Religious Education Due to The Implementation of 4.0 Industrial Era," 2020. Accessed May 5, 2021. https:// eudl.eu/doi/10.4108/eai.30-9-2019.2291133.

S Parviz. "Schools Set to Open Sept. 5 amid Pandemic," September 5, 2020. Accessed October 14, 2020. https:/ / www.tehrantimes.com/news.

Setiawan, Agus. "Implementation of Islamic Education Study Program Learning Based on Blended Learning in the Industrial Era 4.0 at IAIN Samarinda." Dinamika Ilmu: Jurnal Pendidikan 19, no. 2 (December 15, 2019): 305-321.

Shahroom, A. A. and Hussin, N. "Industrial Revolution 4.0 and Education." International Journal of Academic Research in Business and Social Sciences 8, no. 9 (2018).

Sigit Priatmoko. “Memperkuat Eksistensi Pendidikan Islam Di Era 4.0." Ta'lim, Jurnal Studi Pendidikan Islam 1, no. 2 (2018).

Sigit Suryono. "Making Education 4.0 for Indonesia." Rumah Belajar Pena, Oktober 2018. Accessed October 16, 2019. http:// pena.belajar.kemdikbud.go.id/>.

Srivastava, A. K. "Is Education 4.0 the Future of Learning?," n.d. Accessed November 7, 2019. https://www.indiatoday.in/.

Sukartono. "Revolusi Industri 4.0 Dan Dampaknya Terhadap Pendidikan Di Indonesia," 2018. Accessed February 15, 2019. http://semnas.ums.ac.id/. 
Sunan Sripai, Jesada Boonmahome, and Jitirat SaengLoetuthai. "Indicators of the Characteristics of the Graduates of Rajabhat Universities at the Leap Frogging to the Education 4.0." International Journal of Science and Research (IJSR) 7, no. 10 (October 2018).

sutiono. "11 Kelebihan dan Kekurangan E Learning dalam Pembelaran." DosenIT.com. Last modified August 19, 2017. Accessed July 31, 2020. https:// dosenit.com/kuliah-it/teknologi-informasi/kelebihan-dan-kekurangane-learning.

T. Alfaham. "World Muslim Communities Council Organises Virtual Conference on 27th June," $2020 . \quad$ Accessed June 24, 2020. https://wam.ae/en/details/1395302850889.

Tololiu, Rivco. "DPR Desak Kemendikbud dan Kominfo Segera Benahi Jaringan Internet." SINDOMANADO, June 18, 2020. Accessed August 7, 2020. https:// sindomanado.com/2020/06/18/28462/.

Ukkasyah Abdul Qohhar. "Pembelajaran Secara Online Dari Segi Agama Islam keluhkesah.com," $\quad$ n.d. Accessed July 31, 2020. https:// keluhkesah.com/pembelajaran-secara-online-dari-segi-agama-islam/.

Umi Kalsom Kassim and K. Teng Phuah. "Conceptual Study on Enhancement of Education 4.0 from Management Perspective." The 10th InternationalConference on Language, Education, and Innovation. (April 14, 2018).

Vichian Puncreobutr. "Education 4.0: New Challenge of Learning." St. Theresa Journal of Humanities and Social Sciences 2, no. 2 (July 2016).

Wasis D. Dwiyogo. "Pembelajaran Berbasis Blended Learning - Design Blended Learning and Online Education," 2018. Accessed August 4, 2020. https://bl.curriculumdesignhe.eu/pembelajaran-berbasis-blended-learning/.

Yohanes Enggar Harususilo. "Upaya Mendorong Pendidikan 4.0 Indonesia Dari Bali." Kompas.Com, 2018. Accessed October 16, 2019. https:// edukasi.kompas.com/.

Zaenal Nur Arifin. “Dukung Pendidikan 4.0 Di Indonesia, SMK Bina Prestasi Bersama Kompas Gramedia Wujudkan Smart Library," March 12, 2018. Accessed February 15, 2019. https:/ / bali.tribunnews.com/2018/12/03/.

Zubair Torwali. "Education and a Pandemic," April 30, 2020. Accessed September 27, 2020. www.thenews.com/pk. 
AKADEMIKA: Jurnal Pemikiran Islam

Vol. 26, No. 01 Januari - Juni 2021 